\title{
Examining Job Description to Develop Job Performance Indicators for Higher Education Institution Based on MBNQA Education Criteria
}

\author{
Mery Citra Sondari \\ Department of Management and Business, Faculty of Economics and Business \\ Universitas Padjadjaran, Bandung-Indonesia \\ m_citra@yahoo.com
}

\begin{abstract}
Higher Education Institution quality has important impact to national development, in this knowledge-based economy ages. However Higher Education Institutions (HEI) in Indonesia is far lag behind, compare to some of contries in the region of South East Asia.Therefore, HEI in Indonesia should benchmark to World Class Performance Frameworks, one of them is MBNQA. This paper aims to develop job performance indicators as guidance for HEI administrator to be able to achieve the MBNQA criteria. This paper linking organizational performance measurement indicators based on MBNQA, with individual job's performance indicator. From case study at Faculty of Economics and Bussiness Universitas Padjadjaran, Indonesia, by using descriptive content analysis of actual job description, this research find that the MBNQA indicators are not fully covered in actual job description. Further research is still needed to validate the proposed job performance indicators.
\end{abstract}

Keywords: MBNQA, Job Performance Indicators, Higher Education

\section{Introduction}

In recent decades, we have faced the emerge of 'knowledge society' (Bleiklie, 2007) or as is described by Delanty (2001) as "learning societies in a high degree of knowledge". The Role of Higher Education Institution (HEI) in knowledge-based societies has acknowledged by many scholars, for instance Etzkowitz and Leydesdorff (2000) with his triple-helix thesis, and also Bercovitz \& Feldmann (2006) that mentioned the role of university in innovation system. Some important roles of HEI, first, HEI produce knowledge worker that the needs is increase in today circumstance. Second, HEI as one of the core of the science system contributes to the knowledge economy through the key functions of: i) knowledge production - developing and providing new knowledge; ii) knowledge transmission - educating and developing human resources; and iii) knowledge transfer - disseminating knowledge and providing inputs to problem solving (OECD,1996). According to Chen (2008), based on trend in global knowledgebased economy, national competitiveness depends on the continuous knowledge innovation which is one of role of HEI. Knowledge-based economy is one form of economy system as a result from economy evolution where the main source of wealth in market economies has switched from natural assets, through tangible created assets, to intangible created assets (Dunning, 2002). Deriving from its mission, HEI can contribute to increase Knowledge Economy Index (KEI). KEI shows the attainment of a country in knowledge economy ages. Compare to some countries in the neighbourhood, Indonesia have delicate position, as shown in figure 1. Indonesia is at the bottom, compare to Singapore, Malaysia, Thailand and Filipines.

Figure 1: Comparison of Knowledge Economy index between Indonesia and its neighborhood countries

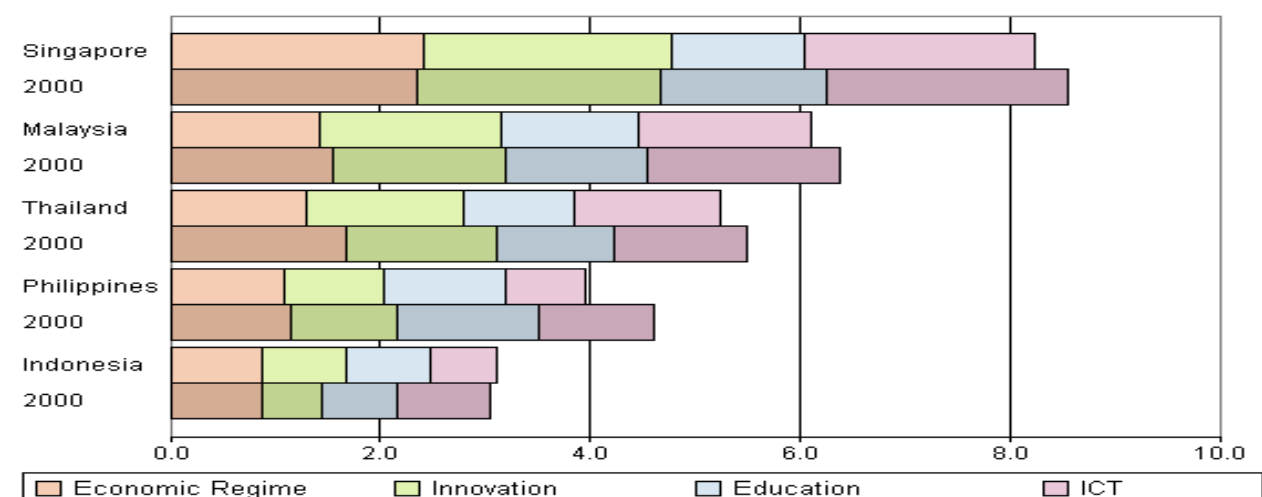

Source : World Bank, 2012 
World Bank has develop several indicators to measure KEI of a contry, that is comprised of four dimensions: economic regime, innovation, education and ICT. The role of HEI, the most is in innovation and education indicators. So that we can say that the attainment of KEI of Indonesia is related to the quality of Higher Education Institution in Indonesia. In sceptical tone, Sukirno and Siengthai (2011) conclude that HEI in Indonesia, is still underdeveloped, no matter what the leader of HEI in Indonesia say to justify the situation. They said, "By having such a condition, it would be still very difficult for Indonesian universities to compete internationally with other foreign universities". Competition among HEI is undeniable, as one of the consequence of the growth of knowledge based economy in globalization era. Globalization has influenced Higher Education Institutions to become more competitive than ever. They compete for status and ranking, or for funding from governmental or private sources (Altbach, Reisberg \& Rumbley,2009). Bleikly (2007) mentioned two mechanism that form the competitive position of a higher education system, which are accreditation and ranking. As a matter of fact, Indonesian HEI competitiveness level is very feeble. Although the practices of accreditation and ranking is common internationally, Higher Education Institutions in Indonesia do not have the same level of readiness to fullfil the requirement of accreditation/ ranking criteria, made by accreditation board / ranking agency, even for National Accreditation standard, made by Higher Education National Accreditation Board. Table 1 , shows the competitve position of big three Indonesian Higher Education Institution internationally, in 2012.

Table 1: Rank of Big Three Indonesian Higher Education Institution in 2012 based on International Rank Agency

\begin{tabular}{|c|c|c|c|c|c|}
\hline & $\begin{array}{l}\text { URAP } \\
\text { (country } \\
\text { ranking) }\end{array}$ & $\begin{array}{l}\text { QS (Asia/ } \\
\text { World) }\end{array}$ & $\begin{array}{l}\text { Webometrics } \\
\text { (Asia / world) }\end{array}$ & $\begin{array}{l}\text { Shanghai (top } \\
500 \text { world } \\
\text { ranking) }\end{array}$ & $\begin{array}{l}\text { THES (top } \\
500 \text { world } \\
\text { ranking) }\end{array}$ \\
\hline $\begin{array}{l}\text { Universitas } \\
\text { Indonesia }\end{array}$ & 1 & $59 / 273$ & $53 / 581$ & Exclude & exclude \\
\hline $\begin{array}{l}\text { Universitas Gadjah } \\
\text { Mada }\end{array}$ & 2 & $118 / 401$ & $30 / 440$ & Exclude & exclude \\
\hline $\begin{array}{l}\text { Institut Teknologi } \\
\text { Bandung }\end{array}$ & 3 & $113 / 451$ & $33 / 497$ & Exclude & exclude \\
\hline
\end{tabular}

Source: data from each website, processed by author (march, 2013)

In order to meet international standards, Higher Education Institution, needs to enhance its quality. Chen, Wang, and Yang (2009) suggest HEI to develop performance measurement indicators that should be understood by everyone in organization. Therefore, this paper seek to answer the question : What are likely job performance indicators that should be applied in Higher Education Institution, in order to can fulfill the criteria of World Class University. This paper has objective to develop job performance indicators based on MBNQA Education Criteria based on actual job description document. MBNQA Education criteria is chosen as it is the most popular performance framework. It becomes guideline for bussiness company to achieve performance excellence in many countries in the world (Ruben et.al.,2007; Islam, 2007; Khampirat, 2009).

\section{Literature Review}

Performance measurement system can be examine in multi-level, organization and individual job. This paper linking organizational performance measurement indicators based on MBNQA, with individual job's performance indicator.

Performance Measurement System: Chen, Wang \& Yang (2009) define performance measurement as a standard used quantitatively to measure organization output systematically regarding to the objective of the organization. It is important for HEI to conduct measurement of its performance because it assists HEI in improving education quality and helps HEI meet stakeholders demands and fulfil their responsibilities to its stakeholders (Chen, Wang, \& Yang, 2009). According to Parmenter, (2010), there are four types of performance measures including Key result indicators (KRIs) that measure the achievement of critical success factors; Result Indicators (RIs) that measure what have been done; Performance indicators (Pis) that tell you what to do; and KPIs that show and measure critical element that can increase performance. The performance indicators are "tools to measure strategic target achievement and ensure that strategic operation is workable" (Chen, Wang, \& Yang, 2009). Individual job performance measurement ( or more well-known as performance appraisal) has a strategic role as it helps 
organization to achieve its goals. It is the process of how organization gets information on how well an employee is doing his or her job (Noe, et.al, 2010). Performance appraisal is one of the function of (employee) performance management which is the processesused to identify, encourage, measure, evaluate, improve and reward employee performance (Mathis and Jackson, 2006).

So that in performance appraisal, there is not only measure activities, but also includes identify the job and its standard before measure the actual performance, and evaluate or giving feedback to employee, after measure the actual performance (Dessler, 2005). What is doing in this research is the first stage of performance appraisal, which is identify the performance standard based on job description. Performance is defined as "the record of outcomes produced on a specified job function or activity during a specified time period" (Bernardin and Russel, 1998). In their book, Bernardin and Russel (1998) adapted Bernardin et.al's (1998) prescriptions for effective performance management, that performance should be defined with a focus on valued outcomes. The outcomes should be defined in terms of relatif frequencies of behavior, and it should be linked to meet both internal and external customer requirements. According to Mathis and Jackson (2006), there are three types of information that can be included in the performance criteria, those are trait based, behavior based, and result based. Trait based information of performance criteria is information about attribut of trait of employee. Behavior based information is information about what employee are doing to do his/her job. Result based information is information about what employee has achieved or produce. Mathis and Jackson suggest that result based information is more usefull.

Malcolm Baldrige National Quality Award (MBNQA): MBNQA Education Criteria for Performance Excellence (2004) consists of seven key dimensions that explain what processes, procedures, and outcomes are associated with a quality organization (Khampirat, 2009), they are: (1) leadership; (2) strategic development; (3) Measurement, analysis and knowledge management; (4) Faculty \& staff focus; (5) Process management; (6) student, stakeholder, and market focus and satisfaction; and (7) organizational performance result (NIST, 2004). According to Ruben, et.al, (2007) there are some benefit of using MBNQA for higher education. The MBNQA framework provide standard of excellence that is commonly accepted and appropriate both for the organization wide and in a specific department level. It is can easily adapted whether in academics or business. It also can provide highlights both strengths and weaknesses and generate baseline for measurement. The result also can be used to share best practices among sectors and support accreditation models. Previous researchers that examine the indicators of MBNQA Education Criteria are Badri, et.al (2006). In their paper, Badri et.al have been carefully deriving the criteria from Baldrige Education Criteria for Performance excellence into categories to develop an instrument that measured MBNQA Education Criteria using seven-point likert-scale. Those categories are shown in the next table :

Table 2: Categories of MBNQA dimensions

\begin{tabular}{|c|c|c|}
\hline \multirow{2}{*}{$\begin{array}{l}\text { Dimensions } \\
\text { Leadership }\end{array}$} & Sub-dimensions & Categories \\
\hline & Organizational leadership & $\begin{array}{l}\text { senior leadership direction } \\
\text { organizational governance } \\
\text { organizational performance review } \\
\text { responsibility to the public } \\
\text { ethical behavior } \\
\text { support of key communities }\end{array}$ \\
\hline \multirow[t]{2}{*}{ Strategic planning } & Strategy development & $\begin{array}{l}\text { strategy development process } \\
\text { strategic objectives }\end{array}$ \\
\hline & Strategy deployment & $\begin{array}{l}\text { action plan development and } \\
\text { deployment } \\
\text { performance projections }\end{array}$ \\
\hline $\begin{array}{l}\text { Student, stakeholder, and } \\
\text { market focus }\end{array}$ & $\begin{array}{l}\text { Student, stakeholder and } \\
\text { market knowledge } \\
\text { Student and stakeholder } \\
\text { relationship and satisfaction }\end{array}$ & $\begin{array}{l}\text { student knowledge } \\
\text { stakeholder and market knowledge } \\
\text { student and stakeholder relations } \\
\text { student and stakeholder } \\
\text { satisfaction determination }\end{array}$ \\
\hline $\begin{array}{l}\text { Measurement, analysis } \\
\text { knowledge management }\end{array}$ & $\begin{array}{l}\text { Measurement and analysis of } \\
\text { organizational performance } \\
\text { Information and knowledge } \\
\text { management }\end{array}$ & $\begin{array}{l}\text { performance measures } \\
\text { performance analysis } \\
\text { data and information availability } \\
\text { organizational knowledge }\end{array}$ \\
\hline
\end{tabular}


Faculty and staff

Organizational performance results
Work systems

Faculty and staff learning and motivation

Faculty and staff well-being and satisfaction organization and management faculty and staff performance management system hiring and career progression faculty and staff education training, and development motivation and career development work environment, faculty staff support and satisfaction learning centered process support process student learning result student and stakeholder result budgetary, financial and market result faculty and staff result organizational effectiveness result governance and social responsibility result

Adapted from Badri et.al (2006)

Because Badri et al (2006) has successfully derived the indicators of MBNQA Education Criteria, and validated it using Structural Equation Modelling, and the result also support the original Baldrige criteria (2004), therefore I adopt the indicators used by Badri et.al, to be used in this research.

\section{Methodology}

This research is single case study research using qualitative method, which is content analysis, to analyze actual job description document to develop job performance indicator based on MBNQA Education criteria. The indicators MBNQA that be used in this research are those adopted from Badri et.al, (2006) The research took place at Faculty of Economics and Business Universitas Padjadjaran (FEB Unpad). Since there are only several jobs in FEB Unpad that have already formal job description document and to prevent redudancy, so that not all jobs in organization structure are examined in this research. The jobs that was examined, consist of jobs tittle as follow: Dean, Vice Dean for Academic Affair, Vice Dean for General Administrative, Vice Dean for Student Affair, Head of Department, Chief of Study Program. I use several phase of procedures to conduct the research. First, I examined the original Badri et.al's indicators, whether each indicator is relevan to be reffer as job performance indicator. I categorize each indicators and clustered them into four group: group 1. is item that describe what to ddo or what have to be done; group 2. Is item that describe how to do the item from group 1; group 3. Is item that describe how is likely the result of what have been done;and group 4 is others item such as external factors. The follow up procedurs after I categorized the item are shown in table 3 . The first phase remains 95 items to be examined in the next phase. Based on the first phase, I analized the actual job description document and deploy each item of MBNQA. Indicators included in the examination to each job tittle for both group of category 1 and category 2 . The third phase is develop job performance indicators for each job could based on the result of second phase. The items that is not belong to any job become the finding of this research. Due the limit of the objective of the paper, the complete suggested form of job performance indicators is not included in this paper.

Table 3: The First Phase of Content Analysis

\begin{tabular}{lll}
\hline Category & Description & Follow up \\
\hline 1 & What to do or what have to be done & $\begin{array}{l}\text { Determine whose job is it based on actual job } \\
\text { description } \\
\text { Examine whether it is explicitly mentioned in } \\
\text { the job description }\end{array}$ \\
3 & How to do it & $\begin{array}{l}\text { Could not be examined due there is no } \\
\text { measurement } \\
\text { How is likely the result of what have } \\
\text { been done }\end{array}$ \\
Others & & Not examined \\
\hline
\end{tabular}




\section{Case study}

The Faculty of Economics and Business Universitas Padjadjaran (FEB-Unpad) is one of sixteen faculty in Universitas Padjadjaran, Bandung- Indonesia. It is public university which was established by the decree of the government of Republic of Indonesia No. 37/1957 on 24th September 1957. Since its establishment for more than 55 years, the faculty of economics has been growing from two study programs in 1957 to become fourteen study programs right now. FEB Unpad has missions to generate competent graduates in accordance with the demands of world-level users; to conduct the world-class excellent education that is able to access the world's demand; to conduct the professionalism and accountability in the management (of governance) in order to improve its image and trust of stakeholders; and to improve the competence and commitment of educators to take an active role in the development of science and technology in Asia Pacific. FEB-Unpad lead by Dean which is helped by three vice dean: vice dean for academic affair, vice dean for general administrative, and vice dean for student affair. Dean also helped by severaal staff or unit that is directly report to Dean, such as : communication manager, international office manager, e-learning manager, quality assurance team, counselling team, and library. Based on QS-Star university ranking for 2012, Unpad is on the fifth rank of Universities in indonesia. As one of higher educational institution, Unpad also regularly been acredited by National Accreditation Board for Higher Education (BAN PT). Every 4 years, the BAN PT institution will conduct accreditation for each study program under FEB Unpad. Most of its study program is accreditated A (highest degree). FEB Unpad also a member of three international association which are AACSB, AAPBS and ABEST21, and now is on the process of accreditation by ABEST21.

Discussion: From 107 indicators that included the the examination, only 19 indicators that is explicitely mentioned in the actual job description. Based on the category of the indicators, those are explicity mentioned in the actual job description, most of them are category 1, it means that what is explicitly mentioned in the actual job description focuses on "what to do" category rather than "how to do it" category. This imply that the job holder do not accompanied by the direction how do to their job that is expected by the organization, so that they will do the job based on each job holder perception and interpretation. From five jobs that have been examined, Dean has six indicators that explicitly mentioned in the actual job description; Vice Dean for Academic affair has two indicators; Vice Dean for General Administrative has two indicators; Vice Dean for Student Affair has two indicators; Head of Department has four indicators; and Chief of Study Program has six indicators. In general, Vice Dean jobs has very few indicators that explicitly mentioned, because the actual job description for these jobs are very generic. The format for these three jobs are very similar. There are six main item for all three jobs of Vice Dean : Planning; Developing policy; Coordinating; Controling; Developing partnership; and Reporting. Head of Department's actual job description has specificly focused on portfolio management and faculty development, while chief of study program has specificly focused on the program delivery, so that these two jobs have more indicators that included in their job description.

Despite of many description that is written in the job description but not determined as indicators of MBNQA, imply that actual job description do not focused on achievement and performance measurement as being asked by accreditation or performance award criteria such as MBNQA. This (job description) might be positioned as administrative document that must be exist, without knowing what is really a benefit from the existence of the document. Other reasons to answer the question why there are very few of MBNQA indicators that is determined included in the actual job description, that it is still put focus on program in general, directly mentioned the object such as student, faculty, or other stakeholder. It is also involving generic word such as coordinating without specificly describe what really job holder has to do in term coordinating the program. Content analysis to the job description also reveals that not all criteria in MBNQA explicitly mention in actual job description. From six criteria that have been examined, criteria of Measurement, Analysis, and Knowledge Management is the only criteria that is not explicitly mentioned in any actual job description. This imply that actual job descriptions do not put this as a concern. This will effect the actual implementation of the job description where the job holder won't conduct any measurement and analysis as well as knowledge management, because they think it is not their job. Since there is "Quality Assurance" unit in the structure that exclude in this research, I assume the measurement and anaysis criteria is put to be focus of this unit. There are also possibilities that actual implementation has include some indictors of MBNQA without write it down in the job description. Many best practice that really conducted by job holder, not explicitly written in actual job description. Since the actual job description document is one important tool in performance management, it is still have to be improve by adding what is really has been doing to the job description document. 


\begin{tabular}{|c|c|c|c|c|c|c|}
\hline & Leadership & $\begin{array}{l}\text { Strategic } \\
\text { planning }\end{array}$ & $\begin{array}{l}\text { Student, } \\
\text { Stakeholders, } \\
\text { and Market } \\
\text { Focus }\end{array}$ & $\begin{array}{l}\text { Measurement, } \\
\text { Analysis, and } \\
\text { Knowledge } \\
\text { Management }\end{array}$ & $\begin{array}{l}\text { Faculty } \\
\text { and Staff } \\
\text { Focus }\end{array}$ & $\begin{array}{l}\text { Process } \\
\text { Management }\end{array}$ \\
\hline $\begin{array}{l}\text { Dean } \\
\text { Vice Dean for } \\
\text { Academic Affair } \\
\text { Vice Dean for } \\
\text { General } \\
\text { Administration } \\
\text { Vice Dean for } \\
\text { Student Affair } \\
\text { Head of } \\
\text { Department } \\
\text { Chief of Program } \\
\text { Study }\end{array}$ & & & & & & \\
\hline
\end{tabular}

From the examination to the actual job description, I can generate job performance indicators for each job as shown in Table 5.

Table 5: MBNQA criteria that expilictly mentioned in actual job description and the job performance indicators

\begin{tabular}{|c|c|c|}
\hline JOB TITTLE & MBNQA CRITERIA & PERFORMANCE INDICATOR \\
\hline & Senior Leaders create strategic directions & Create strategic directions \\
\hline & $\begin{array}{l}\text { Senior leaders continuously review our } \\
\text { organizational performance }\end{array}$ & $\begin{array}{l}\text { Continuously reviw overall } \\
\text { organizational performance }\end{array}$ \\
\hline & $\begin{array}{l}\text { We allocate necessary resources for carying } \\
\text { out these action plans }\end{array}$ & $\begin{array}{l}\text { Allocate necessary resources for } \\
\text { carying out the action plans }\end{array}$ \\
\hline DEAN & $\begin{array}{l}\text { We have effectivee ways in determining and } \\
\text { ensuring our key SP's }\end{array}$ & $\begin{array}{l}\text { Determine and ensure the key } \\
\text { support process in effective way }\end{array}$ \\
\hline & $\begin{array}{l}\text { We use key performance measures for the } \\
\text { control and improvement of our SP's }\end{array}$ & $\begin{array}{l}\text { Control and improve support } \\
\text { process using key performance } \\
\text { indicators }\end{array}$ \\
\hline & We continuosly improve our SP's to achieve & Continuously improve support \\
\hline & $\begin{array}{l}\text { better performance and to keep current with } \\
\text { organizational needs }\end{array}$ & $\begin{array}{l}\text { process to achive better } \\
\text { performance and to keep current } \\
\text { with organizational needs }\end{array}$ \\
\hline VICE DEAN & Senior Leaders create strategic directions & Create strategic direction in term \\
\hline ACADEMIC & & of academic policy \\
\hline AFFAIR & $\begin{array}{l}\text { Our faculty is actively engaged in support our } \\
\text { key communities }\end{array}$ & $\begin{array}{l}\text { Make sure that the faculty is } \\
\text { actively engaged in sipport key } \\
\text { communities through community } \\
\text { service program }\end{array}$ \\
\hline $\begin{array}{l}\text { VICE DEAN FOI } \\
\text { GENERAL }\end{array}$ & Senior Leaders create strategic directions & $\begin{array}{l}\text { Create strategic direction in term } \\
\text { of general administration policy }\end{array}$ \\
\hline ADMINISTRATION & $\begin{array}{l}\text { We use effective key SP's for supporting our } \\
\text { LCP's }\end{array}$ & $\begin{array}{l}\text { Use effective key SP's for } \\
\text { supporting our LCPs }\end{array}$ \\
\hline $\begin{array}{l}\text { VICE DEAN } \\
\text { STUDENTS }\end{array}$ & Senior Leaders create strategic directions & $\begin{array}{l}\text { Create strategic direction in term } \\
\text { of student affair policy }\end{array}$ \\
\hline AFFAIR & $\begin{array}{l}\text { We continuously build active relationships } \\
\text { with students and stakeholders }\end{array}$ & $\begin{array}{l}\text { Continuously build active } \\
\text { relationships with students and } \\
\text { stakeholders }\end{array}$ \\
\hline & $\begin{array}{l}\text { Our governance system ensures accountability } \\
\text { of staff and faculty members }\end{array}$ & $\begin{array}{l}\text { Make sure the accountability of } \\
\text { faculty members in the } \\
\text { department }\end{array}$ \\
\hline HEAD OF & $\begin{array}{l}\text { We take into consideration changing methods } \\
\text { of delivering educational services }\end{array}$ & $\begin{array}{l}\text { Facilitating Curricullum Review } \\
\text { in each study program }\end{array}$ \\
\hline DEPARTMENT & $\begin{array}{l}\text { We achieve effective communication and skill } \\
\text { sharing across departments and functions }\end{array}$ & $\begin{array}{l}\text { facilitating communication and } \\
\text { sharing forum among faculty and }\end{array}$ \\
\hline
\end{tabular}


Faculty and staff appraisals include personal improvement plans

Our governance system ensures accountability of staff and faculty members

In our planning, we anticipate public's concern with our programs and offerings

We have created a climate conductive to CHIEF OF STUDY PROGRAM learning

We use students/ stakeholders satisfaction information in improve programs/ services

We achieve effective communication and skill sharing across departments and functions

We ensure that our faculty and staff are properly prepared to deliver our LCP study program under the department

Conducting Faculty appraisal and facilitating the development of personal improvement plan

Make sure the accountability of faculty members that is assigned in the study program

Conduct programs and offering planning with considering public concern

Create a climate conductive to learning

using students / stakeholders satisfaction information in improve programs / services

facilitating communication and sharing forum among faculty and students

Ensure that the faculty and staff are properly prepared to deliver the LCP

\section{Implication}

This research has several practical implications for FEB Unpad. Since its actual job description only covered very few of MBNQA indicators, it is better to improve the job description. Many indicators should be covered not by the five jobs has already included in this research, but also other jobs, so that there is a need to develop job description for other jobs such as all six unit/office and research centre unit.

Limitation \& Further Research: This research has several limitation. First, MBNQA indicators used in this research adopt the indicators that are developed by Badri et.al, 2006 in UAE context. It is possible that in Indonesia context, the indicators wil be different. The other limitation that this research only depend on content analysis towrds actual document without conduct triangulation through interview, FGD or Delphi technique, or using other tool such as AHP. Therefore there are many rooms for improvement, and I encourage other researcher to conduct the same research using other approach in other case. Further research is also needed to validate the proposed job performance indicators that have been developed in this paper.

\section{Refferences}

Altbach, P. G., Reisberg, L. \& Rumbley, L. E. (2009). Trends in global higher education: Tracking an academic revolution. A report prepared for the Unesco 2009 world conference on higher education. Retrieved from http://www.uis.unesco.org/Library/Documents/trends-globalhigher-education-2009-world-conference-en.pdf

Badri, M. A., Selim, H., Alshare, K., Grandon, E. E., Younis, H. \& Abdulla, M. (2006). The baldrige education criteria for performance excellence framework: empirical test and validation. International journal of quality \& reliability management, 23(9), 1118-1157

Bernardin, H. J. \& Russell, J. E. A. (1998). Human Resource Management, second edition, McGraw-Hill International editions

Bleiklie, I. (2007). Organizing higher education in a knowledge society. Higher education, 49, 31-59

Chen, C. (2008). Casual modeling of Knowledge-Based Economy, Management Decision, 46(3), 501-514

Chen, S., Wang, H. \& Yang, K. (2009). Establishment and application of performance measure indicators for universities. The TQM magazine, 21(3), 220-235

Delanty, G. (2001). Challenging Knowledge: the University in the Knowledge Society. Buckingham: Open University Press.

Dunning, J. H. (2002). Regions, Globalization, and the Knowledge-Based Economy. Oxford: Oxford University Press.

Dessler, G. (2005). Human Resource Management, tenth edition, Prentice Hall. 
Etzkowitz, H. \& Leydesdorff, L. (2000). The dynamics of innovation: from national systems and "mode 2" to a triple helix of university-industry-government relations. Research policy, 29, 109-123

Islam, R. (2007). MBNQA criteria in education: assigning weights from a malaysian perspective and proposition of an alternative evaluation scheme. International transactions in operational research, 14, 373-394

Khampirat, B. (2009). Application of baldrige education criteria on the assessment of an autonomous university in thailand. presented at the 2009 european conference on educational research (ecer), university of vienna, Austria, September 25-30, 2009. Retrieved from http://student.sut.ac.th/buratin/researchpapers/ECER2009.pdf

Mathis, R. L. \& Jackson, J. H. (2006). Human Resource Management, eleventh edition, Cengage southWestern

NIST. (2004). 2011-2012 Education Criteria for Performance Excellence, National Institute of Standards and Technology, Department of Commerce. Retrieved from http://www.nist.gov/baldrige/publications/upload/2011_2012_Education_Criteria.pdf

Noe, R. A., Hollenbeck, J. R., Gerhart, B. \& Wright, P. M. (2010). Human Resource Management : Gaining A Competitive Advantage, Seventh edition, International edition, McGraw-Hill Education (Asia).

Parmenter, D. (2010). Key Performance Indicators : Developing, Implementing, and Using Winning KPIs, second edition, John Wiley \& Sons, Inc.

Ruben, B. D., Russ,T., Smulowitz, S. M. \& Connaughton, S. I. (2007). Evaluating the impact of organizational self-assessment in Higher education : The malcolm baldrige/excellence in higher education framework. Leadership \& organization development journal, 28(3), 230-250

Sukirno, D. \& Siengthai, S. (2011). Does participative decision making affect lecturer performance in higher education? International journal of educational management, 25(5), 494-508 